\title{
Informed Refusal in Pediatric Practice: a Single Center Experience of a Tertiary Care Children's Hospital
}

\section{Pediatri Pratiğinde Bilgilendirilmiş Ret: Üçüncü Basamak Bir Çocuk Hastanesinin Tek Merkez Deneyimi}

\author{
Mine Korcum ${ }^{1}$ (D), Özlem Bağ ${ }^{2}$, Sevay Alşen Güney ${ }^{3}$ (i) \\ ${ }^{1}$ University of Health Sciences, İzmir Behçet Uz Pediatrics and Surgery Training and Research Hospital, Department of Pediatrics, İzmir, Turkey \\ ${ }^{2}$ University of Health Sciences, İzmir Behçet Uz Pediatrics and Surgery Training and Research Hospital, izmir, Turkey \\ ${ }^{3}$ Dokuz Eylul University Faculty of Medicine, Department of Child and Adolescent Psychiatry and Diseases, Izmir, Turkey
}

ORCID ID: M.K. 0000-0002-7432-9453; Ö.B. 0000-0003-2178-4695; S.A.G. 0000-0003-1064-6115

Citation/Atff: Korcum M, Bag O, Alsen Guney S. Informed refusal in pediatric practice: a single center experience of a tertiary care children's hospital. Çocuk Dergisi - Journal of Child 2021;21(3):254-259. https://doi.org/10.26650/jchild.2021.1003850

\section{ABSTRACT}

Objective: Informed consent and refusal of medical procedure and treatment are patient rights that are used by parents or legal representatives of children. This study was conducted to determine the most common treatments and medical procedures refused by parents, their distribution according to clinics, and the frequency of reporting the refusal as child medical neglect to governmental and/or judicial authorities.

Materials and Methods: In this cross-sectional study, the files in the hospital database of all patients who were admitted to the emergency department, intensive care units, all general pediatrics, pediatric subspecialities and surgery clinics of our hospital between 1 January and 30 June 2019 were retrospectively reviewed. All patients whose medical procedures and treatment were refused during the study period were included in our study.

Results: The study group consisted of 348 patients whose medical procedure and treatment were refused by signing an informed refusal form during the study (median age: 1 year 9 months; Male/Female: 197/151). The overall refusal rate was $2.7 \%$. Most of the refusals had occurred in the emergency department. The most common refused recommendation was hospitalization $(303 / 348 ; 87 \%)$, while the most common refused invasive procedure was lumbar puncture (18/39; $46 \%)$. There were no cases who refused end-of-life support in the study group, including intensive care units and palliative care units. Only $7.5 \%$ of the patients were evaluated as child abuse and neglect, and reported to the governmental/judicial authorities.

Conclusion: Discharge against medical advice, which has been reported to increase in recent years, is the most common form of refusal in our study group. Children whose medical procedures and treatment were refused should be carefully evaluated for child abuse and neglect.

Keywords: Refusal of treatment, refusal of medical procedures, child abuse and neglect, medical neglect, informed refusal öz

Amaç: Aydınlatılmış onam ve beraberinde gelen tıbbi işlem ve tedaviyi reddetme hakkı, çocukluk çağında ebeveynler veya yasal temsilciler tarafından kullanılmaktadır. Bu çalışma, çocukluk çağında reddedilen tıbbi işlem ve tedavilerin neler olduğu ve kliniklere göre dağılımı ile ret sonrası çocuk istismarı ve inmali açısından bildirim sıkığının saptanması amacıyla yürütüldü.

Gereç ve Yöntem: Bu kesitsel araştırma, üçüncü basamak olarak hizmet veren ve aynı zamanda eğitim araştırma hastanesi olan bir çocuk hastanesinde yapıldı. Hastanemiz acil servis, yoğun bakım üniteleri, tüm genel pediatri, yan dal ve cerrahi kliniklerinde 1 Ocak- 30 Haziran 2019 tarihleri arasında izlenmiş tüm hastaların, hastane veri tabanındaki dosyaları geriye dönük olarak incelendi. Belirtilen çalışma süresi boyunca tıbbi işlem ve tedavi reddi yapılan tüm hastalar çalışmamıza dahil edildi.

Bulgular: Çalışma grubu, çalışma süresince tıbbi işlem ve tedavisi, bilgilendirilmiş ret formu imzalanarak reddedilen 348 hastadan oluştu (ortanca yaş: 1 yaş 9 ay; Erkek/Kız: 197/151). Genel ret oranı \%2,7 (348/12844) olarak belirlendi. Tıbbi işlem ve reddin en çok oluştuğu birimin acil servis olduğu görüldü. En sık reddedilen durum, hastaneye yatırılarak izlem (303/348; \%87), en sık reddedilen girişimsel işlem lomber ponksiyon (18/39; \%46) idi. Yoğun bakımlar ve palyatif bakım ünitesi dahil olmak üzere, çalışma grubunda yaşam sonu desteği reddedilen olgu saptanmadı. Hastaların sadece $\% 7,5^{\prime}$ i çocuk ihmali olarak değerlendirilerek adli ve idari makamlara bildirilmişti.

Sonuç: Son yıllarda giderek arttığı bildirilen, tıbbi öneriye rağmen hastaneden ayrılma, çalışma grubumuzda en sık rastlanan ret şeklidir. Tıbbi işlem ve tedavisi reddedilen çocuklar, çocuk istismarı ve ihmali açısından dikkatli değerlendirilmelidir.

Anahtar Kelimeler: Tedavi reddi, tıbbi işlem reddi, çocuk istismarı ve inmali, tıbbi inmal, bilgilendirimiş ret

Corresponding Author/Sorumlu Yazar: Özlem Bağ E-mail: bagozlem78@yahoo.com

Submitted/Başvuru: 02.10.2021 • Revision Requested/Revizyon Talebi: 10.11.2021 • Last Revision Received/Son Revizyon: 11.11.2021 •

Accepted/Kabul: 25.11.2021 


\section{INTRODUCTION}

Informed consent is a process for getting permission before conducting a healthcare intervention on a person after being informed about the diagnosis and treatment methods to be applied, the benefits and risks of other applications that can be an alternative to them, and to comprehend the informed decision without any external intervention $(1,2)$. Obtaining informed permission from parents or legal guardians before medical interventions on pediatric patients has become standard within our medical and legal culture (1). The process consists of a total of five items: competence, information, comprehension, volunteerism, and autonomy (3-5). Autonomy is to enable the individual to have information on the subject, to make decisions independently, and to take action in line with their own values and beliefs. Respect to autonomy in the medical field is a professional obligation and a fundamental patient right (6). If the individual has the competence to give consent for intervention, is adequately informed about the subject, can comprehend the information presented, acts voluntarily, and makes a rational decision about the intervention, he/she would give informed consent. When the individual is a child, parents or their legal surrogates are included in their informed consent process (7).

Children's participation in the medical decision-making process requires open communication between the physician, parent, and the child. Physician-parent-child communication is the basis for both children and parents to be satisfied with medical care, and thus, is an important factor for patient cooperation. Involving children in the treatment plan directly enables them to cooperate in the treatment process. Children's participation also develops a sense of control in themselves facilitating the process of treatment adherence. In addition, involving children in medical decision-making demonstrates respect for children's capacities and can provide them with more opportunities for their development (7-9).

In some circumstances, the refusal of medical intervention or treatment may occur in pediatric practice. Treatment refusal is defined as the overt refusal of the patient or his/her legal guardian of any type of investigative procedure, medical care, or surgery recommended or ordered by medical professionals for a potentially curable disease $(4,10)$. In case of refusal, if the treatment is optional, there is no ethical challenge; but in case of a life-threatening treatment, physicians should evaluate the severity of the situation and the risk-benefit ratio for the patient (11). As much as possible, the use of pressure and force on children and adolescents should be avoided (12). But, if the recommended intervention and treatment will save the child's life or if serious harm may occur in case of refusal, the physician has the obligation to prevent potential harm to the minor $(1,7,13,14)$.

The refusal of hospitalization or leaving hospital before the medical team recommends discharge is called 'discharge against medical advice (DAMA)' which causes ethical, legal, and moral dilemmas in pediatric practice $(15,16)$. It has been reported to increase during the last decade both in adult and pediatric populations with increased risk of mortality and morbidity $(17,18)$.

The aim of the study was to determine the frequency of informed refusal for medical procedures and treatment in pediatric age including DAMA and define the characteristics of the patient groups and departments in which refusal occurs more commonly in pediatric practice.

\section{MATERIAL AND METHODS}

\section{Study design, Patients, and Data}

This is a cross-sectional study conducted in the Behçet Uz Children's Hospital which is a tertiary hospital for children and adolescents. The documents in the hospital database system of all patients who were admitted in our hospital's Emergency Service, Intensive Care Units, Clinics of General Pediatrics and pediatric subspecialties, and Clinics of Pediatric Surgery between January 1 and June 30, 2019, were evaluated retrospectively. The patients and/or their legal guardians who had refused medical procedures and/or treatment in the specified 6-month period were included in our study. Written patient files were also obtained to evaluate the signed refusal forms of the study group. Patients with insufficient file information and/or lack of signed 'informed refusal forms' in the written hospital files were excluded. Patients who had left without signing the 'informed refusal form' and were examined in outpatient clinics were not included in the study.

The patients' demographic and clinical characteristics (gender, age, diagnosis, presence of chronic disease, medical procedure/ intervention refused, department in which the refusal occurs, time of refusal, post-refusal notification) were recorded. As patient files of the Emergency Department (ED) did not include detailed demographic properties of the patients, sociodemographic data were obtained for only hospitalized patients.

\section{Legal aspect}

The Turkish Ministry of Health has legalized the right of treatment refusal for adult patients (Regulation No. 25). Legal guardians also have the right to refuse any type of medical treatment on behalf of the minors under their guardianship (Regulation No. 24, 26) (19).

\section{Ethics}

This is a retrospective analysis of patient records and does not include any personal identification data. The study was carried out after it was approved by the Ethics Committee of the Behçet Uz Children's Hospital (Approval date: 19.12.2019 Approval number: 2019/17-11).

\section{Statistics}

Statistical analyses of the data obtained from the study were performed using the SPSS version 22.0 software. The main statistics used are frequency distributions and percentage calculations. Categorical data are presented as percentages, whereas numerical data with Gaussian distribution are presented as mean \pm standard deviation. 


\section{RESULTS}

The study group included 348 children [median age: 1 year 9 months (minimum 12 days - maximum 18 years); male/ female: 197/151] whose parents had signed an 'informed refusal form' for any medical intervention and/or treatment during the study period. According to hospital records, the total number of patients who were hospitalized and followed up was 12844 in the same period (between January 1, 2019, and June 30,2019$)$, thus, the refusal rate was determined as $2.7 \%$. Most of the refusals had occurred in ED ( $n=176 ; 50.6 \%)$ and Clinics of Pediatrics including General Pediatrics and pediatric subspecialties ( $n=126 ; 36.2 \%$ ). Only twenty patients $(5.7 \%)$ were from the Neonatal Intensive Care Unit (NICU), all of which were from $1^{\text {st }}$ degree $\mathrm{NICU}$, and $3(0.9 \%)$ were from the Surgical Intensive Care Unit (SICU). There were no patients from the Pediatric Intensive Care Unit (PICU). The main characteristics of the study group and distribution according to age groups and departments are presented in Table 1.

Table 1: The main characteristics of the study group and the distribution according to age groups and departments

\begin{tabular}{|c|c|}
\hline Variables & Participants $n=348$ (n,\%) \\
\hline Median age & $\begin{array}{c}1 \text { year } 9 \text { months } \\
\text { (min } 12 \text { days-max } 18 \text { years) }\end{array}$ \\
\hline Male/Female & $197 / 151$ \\
\hline Neonatal & $21(6.0)$ \\
\hline Infant & $105(30.2)$ \\
\hline Pre-school child & 125 (35.9) \\
\hline School child & $51(14.7)$ \\
\hline Adolescent & $46(13.2)$ \\
\hline \multicolumn{2}{|l|}{ DEPARTMENTS } \\
\hline Emergency Department & $176(50.6)$ \\
\hline Clinics of Pediatrics & $126(36.2)$ \\
\hline $\begin{array}{l}\text { Neonatal Intensive Care Unit } \\
\left(1^{\text {st }} \text { degree }\right)\end{array}$ & $20(5.7)$ \\
\hline Surgery Clinics & $19(5.5)$ \\
\hline Palliative Care Unit & $4(1.1)$ \\
\hline Surgical Intensive Care Unit & $3(0.9)$ \\
\hline $\begin{array}{l}\text { Neonatal Intensive Care Unit } \\
\left(2^{\text {nd }} \text { and } 3^{\text {rd }} \text { degree }\right)\end{array}$ & 0 \\
\hline Pediatric Intensive Care Unit & 0 \\
\hline
\end{tabular}

Table 2 presents the rates of informed refusal forms to the total number of patients followed up during the same period in different departments. According to our results, although the low number of patient counts, the highest rate of informed refusals had occurred in the pediatric palliative care unit (5.2\%). All of the refused treatments were offered invasive interventions including LP, urethral catheterization, etc. in this population, and there was no refusal for life-sustaining treatments in this unit during the study period.
Table 2: The rates of informed refusal forms to the total number of patients followed up during the same period in different departments

\begin{tabular}{lcc}
\hline Clinics/Departments & Refusals/Total (n) & (\%) \\
Palliative Care Unit & $4 / 78$ & 5.1 \\
Emergency Department & $176 / 5082$ & 3.4 \\
Clinics of Pediatrics & $126 / 4109$ & 3.0 \\
Neonatal Intensive Care Unit & $20 / 909$ & 2.2 \\
(1 $^{\text {st }}$ degree) & & \\
Surgery Clinics & $19 / 2424$ & 0.7 \\
Surgical Intensive Care Unit & $3 / 399$ & 0.7 \\
Neonatal Intensive Care Unit & 0 & 0 \\
(2 $^{\text {nd }} \mathbf{3}^{\text {rd }}$ degree) & & 0 \\
Pediatric Intensive Care Unit & 0 & \\
\hline
\end{tabular}

Table 3 summarizes the refused medical procedures (hospitalization/ intervention/ examination/ treatment). Most of the refusals ( $n=303,87 \%$ ) were for hospitalization. The parents had mostly refused to stay at the hospital for recommended durations and left the hospital at any stage of the treatment (beginning/continuing) and recorded as DAMA. The rate of DAMA in our hospital during the study period was $2.3 \%$. The most common diagnosis for DAMA were bronchopneumonia/pneumonia ( $n=91,26.1 \%)$, epilepsy/convulsion ( $n=43,12.3 \%$ ), fever with unknown origin (unknown/prolonged) ( $n=28,8 \%)$, and acute gastroenteritis $(n=20,5 \%)$. When evaluated in terms of existing chronic diseases; it was observed that $36 \%(n=128)$ of the patients had a chronic disease. The most common chronic diseases in the study group were neurologic disorders [e.g., epilepsy $(n=31$, $24.2 \%$; cerebral palsy $(n=8, \% 6)$, chronic cardiac disorders $(n=14,10.9 \%)$, and reactive airway disease/asthma ( $n: 13$, $10 \%)$ ]. The rate of prematurity in the study group was $9.3 \%$. The acute and chronic diseases of DAMA patients are presented in Table 4.

Table 3: Distribution of refused medical procedures and interventions

\begin{tabular}{lc}
\hline Refused medical procedures (n=348) & Participants, $\mathbf{n}(\%)$ \\
\hline Hospitalization & $303(87.1)$ \\
Invasive interventions & $39(11.2)$ \\
Physical examination & $3(0.9)$ \\
Ordered medications during hospital stay & $3(0.9)$ \\
Refused interventions ( $\mathbf{n}=39)$ & Participants, $\mathbf{n}(\%)$ \\
Lumbar puncture & $18(46.1)$ \\
Nasogastric tube catheterization & $9(23)$ \\
Surgical operation & $7(17.9)$ \\
Urethral catheterization & $3(7.6)$ \\
Vaccination & $2(5)$ \\
\hline
\end{tabular}


Table 4: Distribution of DAMAs in terms of hospitalization diagnoses and existing chronic diseases

\begin{tabular}{lcc}
\hline Diagnosis For Refusing Hospitalization & Participants, $\mathbf{n}$ & $\%$ \\
\hline Bronchopneumonia/Pneumonia & 91 & 26.1 \\
Epilepsy/Convulsion & 43 & 12.3 \\
Fever With Unknown Origin & 28 & 8.0 \\
(Unknown/Prolonged) & & \\
Acute Gastroenteritis & 20 & 5.0 \\
Chronic Diseases of Patients & & \\
Epilepsy & 31 & 24.2 \\
Chronic Cardiac Disorders & 14 & 10.9 \\
Reactive Airway Disease/Asthma & 13 & 10.0 \\
Prematurity & 12 & 9.3 \\
Cerebral Palsy & 8 & 6.0 \\
\hline
\end{tabular}

Thirty-nine parents had refused a recommended medical intervention for diagnosis and/or treatment. The most common refused intervention was lumbar puncture (18/39, 46\%). Other interventions refused by parents were nasogastric tube insertion $(11 / 39,28 \%)$, surgical operation $(7 / 39,17 \%)$, and insertion of urethral catheter (3/46, 7\%) (Table 3).

When we evaluated the parents who signed the refusal form, 209 of them were mothers (60\%), 123 (35.3\%) were fathers, and $16(4.6 \%)$ were the mother and father, together. There were no informed refusal forms signed by the children and adolescents. $47.7 \%(n=166)$ of the refusals had occurred during working hours while $52.3 \%$ ( $n=182$ ) occurred during duty hours. Only 26 refusals (7.5\%) were evaluated to threaten the child's well-being by the medical professionals, and reported to judicial authorities as child abuse and neglect.

Thirty-seven of the patients were Syrian refugees (37/348; $10.6 \%)$. Sociodemographic properties including educational levels of the study group were evaluated in only hospitalized patients $(n=172)$. $3.2 \%$ of the mothers were illiterate while $37.7 \%$ of the mothers were elementary school graduates, $21.1 \%$ were secondary school graduates, $23 \%$ were high school graduates, and $6.1 \%$ were graduated from university/higher. The rates of being illiterate, graduating from elementary school, second-degree school, high school, and university/higher education among fathers were $1.8 \%, 35.7 \%, 24.8 \%, 24.4 \%$, $10.8 \%, 2.5 \%$, respectively.

\section{DISCUSSION}

The results of this study show that the overall refusal rate of medical procedures including discharge against medical advice (DAMA) and refusal of invasive medical interventions is $2.7 \%$ in pediatric patients. The most common type of informed refusal was DAMA in our study group that constitutes $87 \%$ of the study group and thus, the rate of DAMA was $2.3 \%$ in our hospital. The rate of DAMA is known to vary across countries, age groups, diseases, and hospital departments and accounts for approximately $1-2 \%$ of all hospital discharges among adult patients while the rates of DAMA among pediatric patients are reported to range from $1.5 \%$ to over $6 \%$ (20-22). A very recent study from Australia reported that the overall rate of DAMA seen in their cohort was $0.8 \%$ of all admissions (23). Osuorah et al. (24) have suggested that DAMA rates are two times higher in low and middle-income countries than in highincome countries; most likely related to financial issues. In our country, all children are treated for free due to the government health insurance policy in hospitals, including the hospital where the study was conducted and financial problems cannot be reasons for refusing hospitalization in this study group. Thus, although the rate of DAMA in our study seems to be similar to previous reports, we can speculate that this is a relatively high rate despite the lack of financial problems.

According to our results, $50.6 \%$ of the refusals had occurred in ED. The reason for this may be related to the nature of the ED. Admissions to emergency services require urgent evaluation and prompt interventions. However, the informed consent process requires adequate time and care for being informed about the diagnosis, the planned interventions and treatment methods, and the benefits and risks of alternative applications. Although this study did not evaluate the reasons for refusal from ED, we can speculate that allocating more time and care during the informed consent process may reduce the rate of refusals in all departments including ED. Sealy et al. (23) have recently reported that planned admissions were less likely than emergency admissions to refuse treatment in the study in which they described the rates and characteristics of a pediatric tertiary care setting. The authors hypothesized that this was related to patients' and their families' expectations and capacity to plan life conditions. In our study, there were no cases of informed refusal in PICU, and $2^{\text {nd }} 3^{\text {rd }}$ degree NICU, while only 12 cases had DAMA in $1^{\text {st }}$ degree NICU. There was not any refusal for life-sustaining treatment in ICUs in the study group. Only 2 patients had refused chemotherapy for recurrence of the primary oncologic disease in which the expected benefit of the treatment was low. When we evaluated the rates of refusals in different departments of our hospital, the highest rate of refusals was observed in the pediatric palliative care unit. All of the refusal types observed in the palliative care unit were the refusal of invasive procedures; in addition, none of the refusals were about limiting life-sustaining treatment, indicating that the parents do not desire their children to suffer invasive interventions during hospitalization.

In a previous study from our country, Gündüz et al. (25) reported that lumbar puncture was the second most commonly refused treatment following the refusal of hospitalization just as observed in our current study. The most common refused interventions were lumbar puncture $(18 / 39,46 \%)$, nasogastric tube insertion $(11 / 39,28 \%)$, surgical operation $(7 / 39,17 \%)$, and insertion of urethral catheter $(3 / 39,7 \%)$ in our study group. Parental refusal rates for offered pediatric LP are known to be high, often exceeding $30 \%$. Although the rates of LP refusal tend to be lower in high-income countries, in several studies it was observed that LP refusal is not associated with economic status 
among individuals (26). The results of a very recent study showed that the rate of LP refusal among offered patients was only $5 \%$ in our country (27). During the study period, we do not know the number of patients offered LP in our hospital and thus, the results of this study do not reveal the rates of LP refusal among patients that were indicated for diagnostic/therapeutic purposes.

Refusal of medical and surgical interventions other than medications is common among patients with advanced chronic disease in the adult population(28), but there is no data reported about having chronic diseases increase the risk of treatment refusal or not in the pediatric population. The rate of having a chronic disease in our study group was $36 \%$. Although the rate of children with chronic diseases in the study group seems to be higher than in the pediatric population, our data was limited to evaluate whether chronic disorders affected refusal of treatment rates. Prospective studies should be conducted to evaluate a possible relationship between chronic diseases and refusal of treatment in the pediatric population.

In the revised policy statement of the American Academy of Pediatrics in 2016, it is affirmed that patients should participate in the decision-making process commensurate with their development; they should provide assent to care whenever reasonable (29). Although it is clearly supported that children with sufficient maturity to understand the nature and effect of healthcare treatment are able to consent to that treatment, there are some conflicts about refusals. A child's capacity to consent to treatment has not been extended to refusal of treatment in many court decisions, and though a competent child is able to consent, they may not necessarily be competent to refuse that same treatment (30). All of the refusal forms were signed by the parents in the study group (by mothers $60 \%$, by father $35.3 \%$, and $4.6 \%$ both). There was no signature of the patients on the informed refusal forms including adolescent patients in our study group.

After treatment is refused by parents, pediatricians should consider their legal and ethical duties to provide a standard of care that meets the pediatric patient's needs and rather than the parents' desire or request (29). Although historically and legally, medical decision-making in children has focused on the best-interest standard, and set the threshold for intervention in cases of abuse and neglect, the best interest standard proves dificulties in practice $(31)$. Diekema $(32,33)$ has suggested that the Harm Principle provides a more appropriate threshold for state intervention than the Best Interest standard. In our study, only $7.5 \%$ of the refusals were reported to governmental authorities, supporting that the 'harm principle' is being used as the threshold of reporting child abuse and neglect in our hospital, too.

The sociodemographic properties were only evaluated in hospitalized patients except for ED, and were limited to the educational status of the parents. Prospectively designed studies evaluating sociodemographic properties should be conducted to evaluate sociodemographic risk factors for refusal of treatment in pediatric practice.

\section{Limitations}

This study was conducted in the ED and inpatient departments of a tertiary care hospital for the pediatric age and provides data about the informed refusal of treatment in acutely ill children. Other limitations of this study depend on the retrospective design. Researchers firstly evaluated electronic files if any refusal of treatment was recorded on the hospital database system. In case of missing data on electronic patient files, the written patent files were not checked by the researcher, thus the number of patients with a refusal of treatment may be slightly higher than reported. In addition, as the standard written informed consent forms used in our hospital do not include information about the reasons for refusal and sociodemographic properties of the families, we were unable to evaluate the reasons and sociodemographic risk factors of treatment refusals.

\section{CONCLUSION}

Discharge against medical advice is the most common type of refusal to treatment in this study which was previously reported to increase over the past decade and carry a risk of readmission and have increased morbidity and mortality. Among the invasive interventions, lumbar puncture is the most commonly refused medical intervention in the study group, which is also reported to have a significant effect on the treatment, hospital stay, and disposition outcomes in pediatric settings (34). Most cases of refusal of treatment occur in ED but patients in the pediatric palliative care unit have higher rates of refusal of invasive procedures. There were no cases to refuse life-sustaining support either in the ICUs or the palliative care unit in pediatric practice.

Etik Komite Onayı: Bu çalışma Behçet Uz Çocuk Hastanesi Etik Kurulu tarafindan onaylanmıştır (Onay tarihi: 19.12.2019 Onay numarası: 2019/17-11).

Bilgilendirilmiş Onam: Katılımcılardan bilgilendirilmiş onam alınmıştır.

Hakem Değerlendirmesi: Dış bağımsız.

Yazar Katkıları: Çalışma Konsepti/Tasarım- Ö.B., S.A.G.; Veri ToplamaM.K.; Veri Analizi/Yorumlama- M.K., Ö.B., S.A.G.; Yazı Taslağı- M.K.; İçeriğin Eleştirel İncelemesi- Ö.B., S.A.G.; Son Onay ve Sorumluluk- M.K., Ö.B., S.A.G.

Çıkar Çatışması: Yazarlar çıkar çatışması beyan etmemişlerdir.

Finansal Destek: Yazarlar finansal destek beyan etmemişlerdir.

Ethics Committee Approval: This study was approved by the Ethics Committee of the Behçet Uz Children's Hospital (Approval date: 19.12.2019 Approval number: 2019/17-11).

Informed Consent: Written consent was obtained from the participants.

Peer Review: Externally peer-reviewed.

Author Contributions: Conception/Design of Study- Ö.B., S.A.G.; Data Acquisition- M.K.; Data Analysis/Interpretation- M.K., Ö.B., S.A.G.; 
Drafting Manuscript- M.K.; Critical Revision of Manuscript- Ö.B., S.A.G.; Final Approval and Accountability- M.K., Ö.B., S.A.G.

Conflict of Interest: Authors declared no conflict of interest.

Financial Disclosure: Authors declared no financial support.

\section{REFERENCES}

1. Katz AL, Webb SA; COMMITTEE ON BIOETHICS. Informed Consent in Decision-Making in Pediatric Practice. Pediatrics 2016;138(2):e20161485. doi: 10.1542/peds.2016-1485.

2. Kaushik JS, Narang $M$, Agarwal N. Informed consent in pediatric practice. Indian Pediatr 2010;47(12):1039-46. doi: 10.1007/ s13312-010-0173-4.

3. Steinberg A. Disclosure of information and informed consent: ethical and practical considerations. J Child Neurol 2009;24(12):1568-71. doi: 10.1177/0883073809337033.

4. Appelbaum PS. Clinical practice. Assessment of patients' competence to consent to treatment. N Engl J Med 2007;357(18):1834-40. doi: 10.1056/NEJMcp074045

5. Roberts LW. Informed consent and the capacity for voluntarism. Am J Psychiatry 2002;159(5):705-12. doi: 10.1176/appi.ajp.159.5.705

6. Entwistle VA, Carter SM, Cribb A, McCaffery K. Supporting patient autonomy: the importance of clinician-patient relationships. J Gen Intern Med 2010;25(7):741-5. doi: 10.1007/s11606-010-1292-2.

7. De Lourdes Levy M, Larcher V, Kurz R. Informed Consent/ Assent in Children. Statement of The Ethics Working Group of the Confederation of European Specialists in Paediatrics (CESP). European Journal of Pediatrics 2003;162:629-33.

8. McCabe MA. Involving children and adolescents in medical decision making: developmental and clinical considerations. J Pediatr Psychol 1996;21(4):505-16. doi: 10.1093/jpepsy/21.4.505.

9. Spinetta JJ, Masera G, Jankovic M, Oppenheim D, Martins AG, Arush $B$, et al. Valid informed consent and participative decisionmaking in children with cancer and their parents: A report of the SIOP working committee on psychosocial issues in pediatric oncology. Pediatric Blood \& Cancer 2003;40(4):244-6.

10. Appelbaum PS, Roth LH. Patients who refuse treatment in medical hospitals. JAMA 1983;250(10):1296-301.

11. Kuther TL. Medical decision-making and minors: issues of consent and assent. Adolescence 2003;38(150):343-58.

12. American Academy of Pediatrics Committee on Bioethics. Informed Consent, Parental Permission and Assent in Pediatric Practice. Pediatrics 1995;95(2):314-7.

13. Berger JE, Consent by proxy for nonurgent pediatric care. Pediatrics 2003;112(5):1186-95.

14. Stultiëns L, Goffin T, Borry P, Dierickx K, Nys H. Minors and informed consent: a comparative approach. European Journal of Health Law 2007;14(1):21-46.

15. Alfandre DJ. "I'm Going Home": Discharges against medical advice. Mayo Clinic Proceedings 2009;84(3):255-60.

16. Macrohon BC. Pediatrician's perspectives on discharge against medical advice (DAMA) among pediatric patients: a qualitative study. BMC Pediatr 2012;12:75. doi:10.1186/1471-2431-12-75.

17. Spooner KK, Salemi JL, Salihu HM, Zoorob RJ. Discharge against medical advice in the United States, 2002-2011. Mayo Clin Proc 2017;92:525-35.
18. Glasgow JM, Vaughn-Sarrazin M, Kaboli PJ. Leaving against medical advice (AMA): Risk of 30-day mortality and hospital readmission. J Gen Intern Med 2010;25:926-9.

19. T.C. Sağlık Bakanlığı Hasta hakları Yönetmeliği 24-26 Madde Resmi Gazete, Tarih: 01.08.1998; Sayı: 23420. Available at: https://www. mevzuat.gov.tr/mevzuat?MevzuatNo=4847\&MevzuatTur=7\&Mev zuatTertip=5 Accessed 21 March 2014.

20. Yong TY, Fok JS, Hakendorf P, Ben-Tovim D, Thompson CH, Li JY. Characteristics and outcomes of discharges against medical advice among hospitalised patients. Intern Med J 2013;43:798-802.

21. Kraut A, Fransoo R, Olafson K, Ramsey CD, Yogendran M, Garland A. A population-based analysis of leaving the hospital against medical advice: incidence and associated variables. BMC Health Serv Res. 2013 Oct 14;13:415. doi: 10.1186/1472-6963-13-415.

22. Roodpeyma $S$, Hoseyni SA. Discharge of children from hospital against medical advice. World J Pediatr 2010;6(4):353-6. doi: 10.1007/s12519-010-0202-3.

23. Sealy L, Zwi K, McDonald G, Saavedra A, Crawford L, Gunasekera H. Predictors of Discharge Against Medical Advice in a Tertiary Paediatric Hospital. Int J Environ Res Public Health 2019;16(8):1326. doi: 10.3390/ijerph16081326.

24. Osuorah CD, Ndu IK, Asinobi IN, Ekwochi U. Discharge against medical advice (DAMA) among the paediatric age group in Enugu State University Teaching Hospital Parklane. Enugu J Exp Res 2016;4:55-62.

25. Gündüz RC, Halil H, Gürsoy C, Çifci A, Özgün $S$, Kodaman T, Sönmez M. Refusal of medical treatment in the pediatric emergency service: analysis of reasons and aspects. Turk J Pediatr 2014;56(6):638-42.

26. Narchi H, Ghatasheh G, Hassani NA, Reyami LA, Khan Q. Comparison of underlying factors behind parental refusal or consent for lumbar puncture. World J Pediatr 2013;9:336-41. doi:10.1007/s12519-013-0419-z

27. Acoglu EA, Oguz MM, Sari E, Yucel H, Akcaboy M, Zorlu P, et al. Parental Attitudes and Knowledge About Lumbar Puncture in Children. Pediatr Emerg Care 2021;37(7):e380-e383. doi: 10.1097/ PEC.0000000000001594.

28. Rothman MD, Van Ness PH, O'Leary JR, Fried TR. Refusal of medical and surgical interventions by older persons with advanced chronic disease. J Gen Intern Med 2007;22(7):982-7. doi: 10.1007/s11606007-0222-4.

29. American Academy of Pediatrics, Committee on Bioethics. Informed consent in decision-making in pediatric practice [policy statement]. Pediatrics 2016.

30. Moritz D, Ebbs P. Consent and refusal of treatment by older children in emergency settings. Emerg Med Australas 2021;33(1):168-71. doi: 10.1111/1742-6723.13685.

31. Kopelman LM. The best-interests standard as threshold, ideal, and standard of reasonableness. J Med Philos 1997;22(3):271-89.

32. Diekema DS. Parental refusals of medical treatment: the harm principle as threshold for state intervention. Theor Med Bioeth 2004;25(4):243-64. doi: 10.1007/s11017-004-3146-6.

33. Diekema DS. Decision Making on Behalf of Children: Understanding the Role of the Harm Principle. J Clin Ethics 2019;30(3):207-12.

34. Ahmed M, Ejaz M, Nasir S, Mainosh S, Jahangeer A, Bhatty M, et al. Parental Refusal to Lumbar Puncture: Effects on Treatment, Hospital Stay and Leave Against Medical Advice. Cureus 2020;12(4):e7781. doi: 10.7759/cureus.7781. 